\title{
LIMITS ON THE USE OF ECONOMIC ANALYSIS IN JUDICIAL DECISIONMAKING
}

\author{
Patricia M. Wald*
}

\section{INTRODUCTION}

In reading the brochure for this conference, I became somewhat apprehensive to find that I would be crossing pens, and perhaps swords, with so many "economically sophisticated judges." I have had only one freshman course on economics, in 1949 at Connecticut College for Women. Beyond that, my qualifications for writing this article are shaky indeed: A mushy liberal arts major at college, a three year stint at Yale Law School (the old version), a brief touchdown in private practice with Thurman Arnold, and stints in the John Kennedy and Jimmy Carter Justice Departments interrupted by forays into legal services and public interest law. Even my seven years' experience with the heavy regulatory caseload of the D.C. Circuit qualifies me, at best, for amateur status. My nonpedigreed origins are, however, shared by the vast majority of my judicial colleagues. Thus, the remarks contained in this article on the limits of law and economics in judicial decisionmaking, however naive, may serve to forewarn the converted about pitfalls that lie ahead in persuading economically unsophisticated judges to abandon Karl Llewellyn's Bramble Bush ${ }^{1}$ for Judge Posner's Economic Analysis of the Law. ${ }^{2}$

First, let me surface some genuine perplexities about the implications of using the law and economics methodology at all. Can a judge really use economic decisionmaking-at least the way its foremost advocates explain itonly when she so desires, without swallowing the profound philosophical implications it entails for the role of law in society? Can we in the judiciary really be just a "little bit pregnant" with this new movement or will the economics part, like Rosemary's Baby, ultimately devour its legal host? Second, assuming that economic analytical tools can be used to solve specific problems without a commitment to the full-fledged law and economics vision of society, there may be troublesome constraints that flow from the "law" side of law and economics and inhere in the traditional model of a judge as an

Copyright $\odot 1988$ by Law and Contemporary Problems

- Chief Judge, United States Court of Appeals for the District of Columbia; LL.B., Yale Law School, 1951.

The author wishes to thank Stephanie Pollack (J.D. Harvard Law School, 1985) for her assistance and spirited comments in the preparation of this paper.

1. K. Llewellyn, The Bramble Bush: On Our law and Its Study (1951).

2. R. Posner, Economic Analysis of Law (2d ed. 1977). 
arbitrator of disputes between the parties before the court. There are also limitations stemming from the "economics" side of the union, specifically from some of the underlying assumptions and the sometimes incomprehensible language of economics. Finally, this article will discuss problems with two areas of judicial activity where some law and economics proponents would have judges move: basing judges' rulings on predicting behavior ex ante and "at the margin," and interpreting statutes as interest group bargains.

\section{WHAT IS LAW AND ECONOMICS?}

Several years ago, in discussing the more modest enterprise of judicial review of cost-benefit analyses, I concluded that:

[t]he gradual introduction of sophisticated economic concepts and techniques into the [legal] system ... offers great promise for heightening the rationality of . . . judicial review, but equally great caution is in order to insure that they never be allowed to replace justice with cant, or to frustrate genuine judicial understanding of what is involved in each dispute. ${ }^{3}$

My recent reading in the field of law and economics, however, reveals the need to focus on the premises, rather than the promises, of economic analysis. Although some of its proponents eschew the notion that economics can provide a comprehensive and all encompassing philosophy of jurisprudence, ${ }^{4}$ others do not. ${ }^{5}$ Major economic theorists certainly believe that a free market economy enabling maximum free choice by individuals generally maximizes social wealth. This view is shared even by the so called "liberal" practitioners of law and economics who are, however, more likely to believe that the actual marketplace suffers from imperfections. ${ }^{6}$ The major role of courts-and even legislatures-is to back up the free marketplace, leaving a limited role for government to play in advancing equality, redistributing wealth or power, and protecting particular groups from exploitation. The private ordering preferences of the law and economics movement are overt and unabashed.

Many law and economics advocates, among them Judge Bork, assure judges that there exists a middle road between "an enthusiasm so overdone that it leads to the delusion that all of the law's problems can usefully be analyzed through economics ... [and] nihilistic delusion that price theory is so far removed from a science that it is virtually useless anywhere in the law."7 They suggest that judges can pick up or set down the powerful tools of economic analysis like a slide rule, at will. Can that be true, or is a little

3. Wald, Judicial Review of Economic Analyses, I YALE J. ON REG. 43, 62 (1983). (1985).

4. See, e.g., Easterbrook, Method, Result, and Authority: A Reply, 98 HaRv. L. REv, 622, 622-24

5. R. Posner, supra note 2, at 16; Hirshleifer, Evolutionary Models in Economics and Law: Cooperation Versus Conflict Strategies, 4 REs. L. \& ECON. 1, 52-53 (1982).

6. Note, Efficiency and a Rule of "Free Contract": A Critique of Two Models of Law and Economics, 97 HaRv. L. Rev. 978, 979 (1984).

7. Bork, The Role of the Courts in Applying Economics, 54 ANTITRust L.J. 21,22 (1985). 
economic knowledge in the hands of a judge a dangerous thing? Right now the most troublesome limitation on judicial use of economic analysis is the limits of a judge's ability to analyze its techniques and ascertain the extent to which they incorporate assumptions that she is not ready to accept. It may not be easy, or even sensible, for judges to use economic analysis here and there-"on the margin," if you will-to the extent that analysis is fueled by controversial, powerful, and purposefully comprehensive assumptions about human beings, society, and courts.

Some, like Judge Posner, might say this concern comes too late-that courts already operate primarily to further utilitarian ends consistent with the tenets of economics. ${ }^{8}$ My own feeling is that the ad hoc pragmatism of judges, in conjunction with their diverse backgrounds, has thus far prevented the judiciary from becoming a vehicle for the advancement of any powerful new (or maybe old) ideology encompassing the whole of economic, social, and political relationships. Arguably, judges should not abandon that mode for a seductively more organized or coherent decisionmaking framework without fully understanding its assumptions and implications and without exploring whether they can somehow use some but not all of it. Law and economics advocates have the burden of proof in showing judges how their ideology and techniques can be separated, if indeed they can.

Concerns about whether any monolithic economic vision should be incorporated wholesale into judicial decisionmaking are heightened by the fluid nature of law and economics itself. In one sense, the healthy controversy and dissension within the law and economics movement about key concepts is encouraging. These assumptions include: (1) the role of altruism, loyalty, benevolence, rage, and jealousy in individual behavior; ${ }^{9}$ (2) whether courts maximize social wealth better than legislatures; ${ }^{10}$ (3) whether a more equal distribution of income or wealth would reduce efficiency and threaten liberty; " and (4) whether there is evidence for the assumption that individuals bent on optimizing their own preferences will act in harmony over the long haul so as to maximize social good as well. ${ }^{12}$ At the same time, however, these debates make economic philosophy a moving target. For a judge to embark intelligently on a law and economics mode of decisionmaking, she would initially have to devote a great deal of time to probing the underlying assumptions and goals of the movement and then decide, in light of much debate and conflict, which assumptions she agrees with and which tools of economic analysis incorporate those assumptions but not the others.

8. I refer, of course, to Judge Posner's "positive" description of the common law-a category in which he includes at least half the business of the federal courts-as consisting of decisions made by judges "as if their goal were to promote economic efficiency." $R$. Posner, The Federal Courts: Crisis and Reform 314 (1985).

9. G. Akerlof, An Economic Theorist's Book of Tales 1-4 (1984); Hirshleifer, supra note 5, at 36-37, 51-52.

10. Note, The Inefficient Common Law, 92 YALE L.J. 862, 885-87 (1983).

11. G. Stigler, The Citizen and the State: Essays on Regulation 6-8, 14-19 (1977).

12. Hirshleifer, supra note 5 , at 6-8, 49-54. 
In short, law and economics is a serious and controversial intellectual movement, not a fad with which one should lightly ally. That having been said, it is time to move off of this disturbing but very fundamental limit, and on to some of the more practical limits in applying economic analysis techniques in judicial decisionmaking.

The Role of the Courts and the Limits of Economic Analysis

Let us begin with some specific problems which grow out of the constraints of the judicial role. The truism that judicial analysis, economic or otherwise, takes place only in the context of lawsuits between two or more parties imposes a practical constraint on the judge's ability to use economic analysis, particularly when the judge is economically unsophisticated. Such a judge will, for the most part, be limited by what the parties serve up to her. Beyond this practical problem, bothersome questions lurk behind the economists' vision of the role of courts in our society. While judges often make general policy in the process of deciding specific cases, their rationales and rulings should not, as some economists urge, ignore or demote the interests of the parties before them.

\section{A. Problems of Competence}

Judges in the D.C. Circuit review a lot of federal agency cost-benefit analyses which, at least some of the time, have been produced by real economists. Even reviewing somebody else's economic analysis, however, poses problems for the untrained judge who cannot "talk directly to the economists, question the experts, or ensure that every piece of relevant information finds its way into the record."'13 It is infinitely harder to work out the appropriate economic analysis de novo. Judges rely on parties to frame the issues, and serious problems of competence are raised by suggestions that courts should sua sponte invoke and rely on economic principles to decide a case when the parties have not argued the case that way.

In the absence of guidance from the parties, a judge cannot know which economic precepts should be applied to the case at hand or how those precepts should be applied. No immutable set of economic commandments exists to which all economists have sworn fidelity. The Judicial Canons of Economic Construction have not yet been issued, although they are probably in the making. Even if a judge decides that economic analysis is appropriate, she is faced with the choice among classical or neoclassical Chicago School economists, who usually assume that the market is functioning efficiently, and Keynesian liberal economists or post-Chicago School revisionists, who are more likely to spot market failures requiring state intervention. ${ }^{14}$ While in

13. Wald, supra note 3 , at 46 .

14. A. Buchanan, Ethics, Efficiency, and the Market 19-26 (1985); Note, supra note 6, at 979. 
some cases different approaches might yield the same result, in other cases "different economic approaches speak to identical issues differently."15

A judge applying economic analysis in a case where the parties have not chosen to frame their dispute in economic terms will have nothing to go on other than her own knowledge, the published literature, or maybe a law clerk with a Ph.D. in economics (not unheard of these days). If these sources present alternative economic approaches yielding opposite results, the judge must choose among them. Her choice could presumably be based on what appeals to her intuitively, the philosophy of the economics school for judges she has most recently attended, or the views of trade magazines to which she subscribes. If she knows of only one approach, is it fair to the parties to decide the case on the basis of that approach? Can consistency in circuit law survive if different judges choose different modes of economic analysis? Finally, why should a judge do all this work if the parties have not asked for such an analysis? The only discerning answer to the last question may be that a concern for the social good demands it. That answer, however, brings us back to the controversial assertion that the assumptions of market-based analysis are the ones for judges to follow in decisionmaking.

Even a judge who is comfortable applying self-taught economic techniques can run into problems with lack of data. In reviewing cost-benefit analyses conducted by agencies, for example, the D.C. Circuit Court sometimes concludes that the agency lacked sufficient evidence from which to draw its conclusions; in such cases, however, a judge can remand to the agency to gather additional data. ${ }^{16}$ If, where the parties have spent years assembling the economic basis for their case, information can still be lacking, what about lawsuits where the parties have not even framed the issues in economic terms? Yet without adequate data the court can only do a qualitative balancing type of economic analysis, the end result of which would not look much different from the unfettered balancing courts already perform on a daily basis.

Even assuming that all the necessary data and expertise were available for judges to draw on, would economic analyses make decisionmaking easier or more reliable? Given the overload of the courts, most judges will hesitate to further complicate decisionmaking unless they are reasonably sure that the benefits of the new technique outweigh its costs. Although true believers would argue that economics is the only way to make decisions, agnostics would counter that well intentioned policymakers accompanied by mounds of data, graphs, charts, and aides regularly produce economic analyses of uncertain reliability. Highly respected economic policy analysts such as Alice Rivlin have pointed out that information overloads can either paralyze decisionmakers or lure them into simplistic and unrealistic solutions. ${ }^{17}$ If

15. Williamson, Intellectual Foundations: The Need for a Broader View, 33 J. LeGaL Educ. 210,213 (1983).

16. See, e.g., NRDC v. Herrington, 768 F.2d 1355, 1410-25 (D.C. Cir. 1985) (The cost-benefit analysis of appliance efficiency standards lacked adequate factual support for quantifying several benefits and costs.).

17. Rivlin, A Public Policy Paradox, 4 J. Pol'y Analysis \& Mgmt. 17, $18-19$ (1984). 
judges cannot rely on the staff and the computer programs that the professional economists use for their not-so-reliable assessments, how can judges be sure that their rudimentary efforts at forecasting by music-man techniques will not accomplish more harm than good? In the Music Man, Professor Harold Hill tells his students to "think" the tune; is it enough to tell judges to "think economically?"

For all these reasons, judges should think twice about applying general techniques of economic analysis in cases where the parties have not framed the case in economic terms. Perhaps if enough judges demand enough economic analyses, it will prompt more litigants to supply them. Until then, those economically unsophisticated judges who embark on economic excursions of their own without adequate training or a responsible tour guide are of questionable use to both the litigants and the ultimate social good.

\section{B. Doing Justice Between the Parties}

Most parties who come to court are more interested in winning their case than in providing the court with an opportunity to lay down generalized rules of behavior for others. Frequent litigators such as the government, large industrial groups, and insurance companies are exceptions, of course, since they have a bigger stake in precedent and judicial rules. ${ }^{18}$ As things now stand, however, general rules are more the by-product than the primary goal of judicial decisionmaking.

Advocates of economic analysis by judges, however, focus almost exclusively on the rulemaking aspects of the judge's role. For them, courts are and should be yet another societal mechanism for inducing behavior which promotes wealth maximization and efficiency in resource allocation. Thus, judges should worry less about "fair" treatment of the parties before them-whose loss or gain has already occurred-and more about the future effects of their rulings on others who have yet to act. ${ }^{19}$

The economists' vision differs from the more traditional view that a primary role of judges is to do justice between the parties. ${ }^{20}$ Indeed, many define the sin of judicial activism as turning away from the dispute at hand to focus on broader questions of social policy. Yet what else are economists' "rules" but economic and social policy? At the end of the day, is there all that much difference between Professor Chayes' public-policy-oriented, ${ }^{21}$ and Judge Easterbrook's economics-oriented, judiciary? ${ }^{22}$

Obviously, judges must and do entertain concerns about the future effect of their rulings. From time immemorial, they have tested the consequences of their rulings in particular cases against other and different potential fact

18. Note, supra note 10 , at 878,878 n.64, 885 .

19. Easterbrook, The Supreme Court, 1983 Term-Foreword: The Court and the Economic System, 98 HARV. L. REV. 4, 10-12 (1984).

20. This vision of the role of judges dates back at least to the time of DeTocqueville. A. DeTocqueville, Democracy in America 90 (G. Laurence trans. 1966).

21. See generally Chayes, The Role of the Judge in Public Law Litigation, 89 HARv. L. Rev. 1281 (1976).

22. See Easterbrook, supra note 4. 
situations. ${ }^{23}$ Acknowledging this, however, is not the same as acquiescing to a notion that "justice between the parties" is a second level priority, nor is it a giveaway signal that the judge lacks economic sophistication. ${ }^{24}$ "Guideline" rulings, even by the Supreme Court, have always been viewed skeptically among judges; deciding important and controversial issues not before the court is dangerous both because the issues may not have been adequately explored by the parties and because it prematurely silences debate among scholars and lower courts. ${ }^{25}$ Before judges can become convinced that courts should make their primary focus the creation of general rules, they need some better answers to several questions.

First, why must the courts function as still another decisionmaking institution devoted to wealth maximization? There are plenty of societal decisionmaking institutions whose primary function is or should be to lay down general rules of behavior designed to promote efficiency: Congress, the Executive, and administrative agencies. In fact, Judge Posner defines activism as judicial intrusion upon the legitimate policymaking spheres of these coordinate branches. ${ }^{26}$ Furthermore, if, as some economists contend, Congress and the Executive have not promoted efficiency, why place this responsibility on the courts rather than trying to improve the focus and awareness of the democratically elected Congress or President? While an investment in converting or appointing an empathetic judiciary may yield better long term dividends in advancing economists' objectives, that is not necessarily an official tenet of their philosophy.

Perhaps in a comprehensive law and economics framework all societal institutions should be oriented toward wealth maximization. However, because more modest proponents, including some economists, ${ }^{27}$ admit that efficiency is not the only worthwhile societal goal, it must be legitimate to have some societal decisionmakers focusing on other values. Many economists prefer to focus on efficiency and leave "unfairness"-alias disparities in distribution of income, wealth, power, or opportunity-to someone else. Nevertheless, many important legal disputes involve precisely the issue of how such benefits are to be distributed-someone will lose and someone will win or a third party "externality" will be significantly affected. ${ }^{28}$ Before the courts abandon their traditional role of being the "someone else" to whom

23. Even in practicing what my colleague Judge Edwards calls "focused adjudication," judges assess the effects of their rulings on future litigants by extrapolating from the situation of the parties in front of the court. This assessment differs from what Judge Edwards terms "wide-angle adjudication," which involves a broader inquiry into the fields of social and economic life potentially affected by the ruling. Edwards, The Role of Judge in Modern Society: Some Reflections on Current Practice in Federal Appellate Adjudication, 32 CLEv. ST. L. REv. 385, $411-12$ (1983-84).

24. Cf. Easterbrook, supra note 19, at 12.

25. Shapiro, Mr. Justice Rehnquist: A Preliminary View, 90 Harv. L. Rev. 293, 341 (1976).

26. R. POSNER, supra note 8, at 208-11.

27. Markovits, Legal Analysis and the Economic Analysis of Allocative Efficiency, 8 HoFSTRA L. REv. 811 . 14, 89 1-92 (1980); Samuels \& Mercuro, Posnerian Law E' Economics on the Bench, 4 INT'L REv. L. \& ECon. 107, 110-14 (1984); Comment, Posnerian Jurisprudence and Economic Analysis of Law: The View from the Bench, 133 U. PA. L. Rev. 1117,1162 (1985).

28. Hirshleifer, supra note 5 , at $5,46$. 
disadvantaged individuals and groups can turn for "justice," judges need to know who-if anyone-will take over that role.

If law and economics proponents are saying only that judges should be aware of what economic principles can tell us about the efficiency implications of one rule versus another, we might concede gracefully to their position. However, it appears that at least some of them are saying a great deal more: Even if the result is unfair vis-a-vis the parties before the court under traditional equity standards, courts should primarily look at the efficiency, or wealth maximizing effect of a rule as assessed by predicting the future behavior of others not before the court. Thus, Judge Easterbrook warns that "muddy" rules result from trying "to accommodate the needs of parties caught in a web of circumstances," and praises the Supreme Court for, in one case, "bypassing for the most part ... [plaintiff's] case in order to examine how rules affect future behavior." 29 As judges have known for years, framing the issue in a case is three-fourths of the battle. Frankly, I think a judge ought to be cautious about routinely converting the issues put to her by the parties in terms of their own dispute into broad, all-encompassing questions about general rules for social behavior.

In deciding what is fair or just in individual cases, of course, judges must consider what the chosen norm will mean for others similarly situated. The judges' primary focus, however, is on the relationships and actions of the parties before them and not on making a rule for all seasons and situations. Rather than ignoring the parties' needs, judges try to learn what the parties' "web of circumstances" can teach them. It is hard to accept the economists' assumption that everything that has happened to the parties is a "sunk cost" with little or no relevance to the desired outcome of the dispute. The idea that the rights and wrongs of individuals are subordinate to some greater common good is not an alien concept in the law, but it probably should not be embraced as the fundamental precept of all judicial decisionmaking.

I can illustrate my concerns with the following example from my legal service days. We were fighting for an implied warranty of habitability so that a slum landlord could not collect rent for an uninhabitable dwelling. ${ }^{30}$ Our argument was based in part on a notion of fairness between landlord and tenant. A judge in an economic predictive mode might conclude-and would have been right in many instances-that slum landlords would abandon their properties rather than repair them and that poor people would therefore have fewer housing options. Should they then refrain from finding a warranty of habitability? I think not, because to do so they would have had to totally disregard the overwhelming differences in bargaining power between slum landlords and tenants.

In short, a judge's present notions of equity and justice between the parties, however untidy, already include reasonable, sometimes even

29. Easterbrook, supra note 19 , at 7,21 .

30. See Javins v. First Nat'l. Realty Corp., 428 F.2d 1071 (D.C. Cir.), cert. denied, 400 U.S. 925 (1970). 
sophisticated, predictions or judgments about the causes and effects of human behavior. Economic analysis may aid in those predictions, but judges' current emphasis on deciding the cases before them should not be foregone in favor of accepting a different and more amorphous role as a "social wealth maximizer."

\section{IV}

\section{Where Not to Use Economic Analysis}

Robert Cooter has written that while " $[t]$ here may be some areas of law which can be explained by economics, ... there are other areas of law in which economic explanations will always be incomplete."31 I turn now from the limitations of the "law" to the limitations of "economics" to suggest where the use of economic analysis may or may not be legitimate.

Unfortunately, most law and economics proponents have done little to help delineate the appropriate boundaries of economic analysis. Just as Judge Easterbrook has advised judges that they should more often focus on where not to apply a particular statute than on how to apply it, ${ }^{32}$ so, too, judges need guidance on when to use and not to use economic analysis. Too much of the literature has ignored a very practical question that arises for judges who are open to the use of economic analysis: How, especially in the absence of guidance by the parties, is a judge to separate those cases in which economic techniques will be helpful from those where it will not (or even from those cases in which it will be harmful)?

Two of the most important limitations of economics are its underlying assumptions and its language. First, and most important, the very nature of some legal issues renders them inappropriate for economic analysis. Second, the language of economics will sometimes cloud, rather than clarify, the issues at hand and make unacceptable a resolution of the dispute in economic terms.

\section{A. Limitations Based on Economic Assumptions}

How does a judge spot a case in which economic analysis will be helpful? According to Judge Bork, economics is a method of reasoning which "works only when you are dealing with things that are comparable. That is why economics has produced its most valuable results and insights when dealing with the behavior of persons and firms in real markets, where dollars may be used as measuring units." 33 Clearly, economic analysis makes sense in cases involving real market transactions, such as contracts and antitrust where "economic facts" lie at the core of the case.

However, the usefulness of economic analysis extends beyond actual market transactions. Professor Bruce Ackerman notes that economics is a

31. Cooter, Law and the Imperialism of Economics: An Introduction to the Economic Analysis of Law and a Review of the Major Books, 29 UCLA L. REv. 1260, 1266 (1982).

32. Easterbrook, Statutes' Domains, 50 U. ChI. L. Rev. 533 (1983).

33. Bork, supra note 7, at 22. 
form of discourse employed by people involved in bargaining and which can be extended to cases involving "hypothetical bargaining, by real world people." ${ }^{34}$ In such cases economic techniques can help judges to identify the terms that the parties "would have agreed upon, ex ante, if transaction costs had not made it impossible to deal with one another before [they] collided." 35 Torts is an obvious example of a legal subject involving hypothetical bargaining by real world people—or at least "reasonable" prototypes thereof. In torts cases, courts imply that one person has a duty toward another, even when the parites have not agreed that any such duty exists. In effect, the courts infer what the parties would have agreed upon had they met "before they collided." Thus, torts has involved economic analysis since at least 1947 when Judge Learned Hand declared that negligence should be defined as the point at which the marginal benefit to society of taking additional care was greater than the marginal cost to society of that care. ${ }^{36}$

Even Professor Ackerman acknowledges, however, that there are some legal topics which are effectively off limits to economic analysis because bargaining metaphors are inappropriate; we cannot or would not ever imagine bargaining over such issues. ${ }^{37}$ For example, economic analysis is peculiarly unsuited to constitutional and statutory causes of action designed to protect people against racial, gender, or ethnic discrimination based solely on prejudices. While the marketplace may accept the validity of such prejudices, the legal system does not. ${ }^{38}$

Generally, economic analysis is not helpful whenever the assumptions incorporated into economics run fundamentally counter to the rights, duties, or values implicit in our Constitution as interpreted by the courts. Professor Laurence Tribe has identified a "constitutive" role for the courts in defining "the sort of society we are to be." 39 Similarly, Judge Edward Spaeth has argued that judges have a duty "to hold up before us the sort of society we desire, so that we may be helped, not simply to live by our ideals, but to gain in our understanding of what our ideals are and what they may require of us." 40 Judge Linde of the Oregon Supreme Court thinks that courts must and do "shape people's vision of their Constitution and of themselves."41 Unfortunately, as Professor Tribe has argued, an undue emphasis on economic analysis allows judges to evade this role and ignore issues of power and powerlessness, public purpose and private interest, the nature of our laws and Constitution, and the mission of courts vis-a-vis our political system. ${ }^{42}$

34. Ackerman, Foreword: Talking and Trading, 85 CoLum. L. Rev. 899, 903 (1985) (emphasis in original).

35. Id.

36. United States v. Carroll Towing Co., 159 F.2d 169, 173 (2d Cir. 1947).

37. Ackerman, supra note 34 , at 904 .

38. See Markovits, supra note 27 , at 873.

39. Tribe, Constitutional Calculus: Equal Justice or Economic Efficiency?, 98 HARv. L. Rev. 592, 595, 606-14 (1985).

40. Spaeth, Where is the High Court Heading?, Judges, Summer 1985, at 48.

41. Linde, Judges, Critics, and the Realist Tradition, 82 Y ALE L.J. 227, 239 (1972).

42. Tribe, supra note 39 , at 592-93, 620-21. 
Thus Judge Spaeth finds the same Court which Judge Easterbrook lauds for its economically astute rulings to be "drifting," with "no sure sense of values," casually costing out human life and other fundamental liberties against social efficiency. ${ }^{43}$

For at least some of its champions, economics provides the certainty that all seek, a safe harbor from capricious judges, and stability in the midst of chaos. Such certitude, however, may never be achievable, particularly in constitutional adjudication, which has been aptly described by Professor Gene Nichol as "a meandering process by which we seek to assure political and social equality, to etch out those freedoms secured to autonomous individuals, and to define and express ourselves as a society." 44

Even if legal certainty were possible, society-including judges-would pay a heavy price for it. Economic analysis inevitably results in judicial deference to the executive, which has a vastly greater expertise at costing out conflicts and identifying the administrative and managerial costs of a particular rule or policy. ${ }^{45}$ The resort solely to economic analysis bespeaks, in the words of Judge Spaeth, a "loss of nerve" 46 on the part of judges in assuming their constitutive role. While economics may seem like a neutral science, "economists' solutions depend as much on their conception of the public good as on their technical algorithms. As a result, for good or ill, economics is as influential for its implicit ethical theory as for its predictions." 47 The price of economic "certainty" may be reducing constitutional law to a battlefield on which economists continuously joust.

My own, largely pragmatic, view falls somewhere between those who would resolve all disputes by economic analysis, and those who would confine the beast to its antitrust and regulatory cage. Economic analysis obviously has widespread utility, although even in those areas where it dominates there may be more at stake than market trade-offs. ${ }^{48}$ It is, therefore, dangerous to let the economists dictate all of the questions a judge may ask, since that means cutting off the development of facts and evidence which might illuminate even more brightly the underlying issues. ${ }^{49}$ In areas involving fundamental constitutional morality, compelling critiques like Judge Spaeth's can lead to the conclusion that economic analysis has little or no legitimate place.

In between are the grey areas in which a judge needs to inspect the underlying assumptions of economic behavior with caution before wholeheartedly embracing them. For example, one key aspect of economics is

43. Spaeth, supra note 40 , at 11,48 .

44. Nichol, Book Review, 93 YALE L.J. 171, 186-87 (1983).

45. Tribe, supra note 39, at 612-13,620-21; Spaeth, supra note 40, at 48 .

46. Spaeth, supra note 40 , at 48 .

47. Brandl, Distilling Frenzy From Academic Scribbling: How Economics Influences Politicians, 4 J. POL'y Analysis \& Mgmt. 344, 344 (1985).

48. For example, it is far from clear that antitrust law is only about efficiency. See Rothery Storage \& Van Co. v. Atlas Van Lines, Inc., 792 F.2d 210, 218 (D.C. Cir. 1986) (Wald, J., concurring); Hovenkamp, Antitrust Policy After Chicago, 84 Mich. L. Rev. 213, 249-50 (1985).

49. See Gibbons, Antitrust, Law E Economics, and Politics, Law \& Contemp. Probs., Autumn 1987. at 222-23. 
its focus on the individual as a rational maximizer of wealth. A judge might be reluctant to apply neoclassical economic analysis to family law if she believes that this vision of the individual should not apply in the family setting, ${ }^{50}$ or if she is attracted to the ideas of analysts who see the "code of kinship" as an anthropological exception to the maxim of self-interest. ${ }^{51}$ More generally, Professor Cooter has suggested that it is liberty, not wealth, that people most want to maximize. ${ }^{52}$ Other areas of the law may similarly require that behavioral norms and expectations be derived from the context of people's membership in a group rather than as isolated "Lone Rangers" in a pervasive marketplace. ${ }^{53}$

In short, if economics is about individual decisionmakers engaged in bargaining transactions where all choices count equally, it will not be suited to solving legal problems which involve fundamentally different aspects of life and society. At a minimum, in questionable cases judges ought to give the parties a choice to opt out of the economic approach by pinpointing the assumptions of economic analysis which make it unsuitable in their case.

\section{B. Limitations Based on the Language of Economics}

Peculiar problems arise from the use of economic analysis, because the language itself can cloud, rather than clarify the legal issues. Furthermore, phrasing the issues in the mathematical equations of quantitative economics usually does not help matters. ${ }^{54}$ Economic language is a carrier for, and thus no more neutral than, the economic assumptions it conveys. Perhaps in belated recognition of this fact, law and economics scholars have somewhat humorously attempted to popularize their language with references to Jobs as Dam Sites, The Market for "Lemons," and the Economics of Caste and the Rat Race. ${ }^{55}$

Economic language-in some cases economic jargon-can be used to make controversial outcomes seem obvious. Cost-benefit concepts such as "opportunity cost," "production function," and "comparative advantage" sound wise and neutral but may be neither. Candid economists admit that if judges analyze problems in these terms, the battle is all but won; economists always have the solutions to self-defined problems. Often just framing an issue as an "externality," a "public good," a "monopoly," or a "service" makes the solution pre-ordained.

50. Kornhauser, $A$ Guide to the Perplexed Claims of Efficiency in the Law, 8 HofsTra L. REv. 591, 637 (1980); see also Olsen, The Family and the Market: A Study of Ideology and Legal Reform, 96 HARv. L. REv. $1497,1524-25$ (1983) (using assumptions about family life to critique market assumptions).

51. Hirshleifer, supra note 5 , at $26,45-46$.

52. See R. Cooter, Liberty, Efficiency, and the Common Law (1986).

53. See, e.g., Sax, The Legitimacy of Collective Values: The Case of the Public Lands, 56 U. Colo. L. REv. 537 (1985) (environmental law); Spiegelman, Court-Ordered Hiring Quotas After Stotts: A Narrative on the Role of the Web $\xi^{\circ}$ the Ladder in Employment Discrimination Doctrine, 20 HARV. L. REv. 339 (1985) (employment discrimination law).

54. See American Hosp. Supply Corp. v. Hospital Prod. Lid., 780 F.2d 589, 593 (7th Cir. 1986) (Posner, J.) (reduction of traditional standard for preliminary injunction to a mathematical equation).

55. G. Akerlof, supra note 9 , chs. $2,3 \& 6$. 
There is thus a danger that judges will use the language of economic analysis to disguise, or make more credible, nothing more than a generalized balancing of interests. As Judge Bork has pointed out, a judge is not engaging in a genuine cost-benefit analysis merely because she balances competing interests in a case. ${ }^{56}$ True cost-benefit analysis requires the judge to weigh factors which are comparable, and this often involves translating them into monetary terms. When a judge simply weighs competing values which have no common denominator, she engages in traditional legal, not economic, analysis. Similarly, for a true economic analysis, the judge must have some economically acceptable basis for deciding what is a cost and what is a benefit, and for assigning societal values to the various costs and benefits. ${ }^{57}$ If the judge is simply speculating on the future consequences of the legal rule under consideration, she can delude herself and others by labeling it as an economic analysis and arriving at a conclusion based on the language, rather than on the content, of the terms used.

The language of economics in general, and cost-benefit analysis in particular, is not only difficult for noneconomists to work with and understand, it is also often distinctly unsatisfying as a way of rationalizing or explaining legal outcomes. Many judges and litigants will feel cheated when their legal fates and valuable liberties are sealed by decisions couched in economic terms. Professor Laurence Tribe has noted that " $[B]$ ]eing 'assigned' a right on efficiency grounds, after an appraisal of the relevant cost curves, hardly satisfies the particular human need that can be met only by a shared social and legal understanding [of why] the right belongs to the individual." 58 This is true not only in the constitutional context where, as Judge Spaeth has warned, "critical passions will be aroused when issues of such fundamental importance as religious freedom are analyzed in terms as barren as a balance of costs and benefits," 59 but in other situations as well. Judge Bork has perceptively noted that nothing "is really gained in rigor, in sophistication, in precision, or in enlightenment, by restating ... [some legal] problems in terms of cost-benefit analysis." 60

The role of language in economics is paramount, so the move to enhance the role of economic analysis in the law is a move to change the nature of legal discourse. Yet it makes no sense to adopt a new language unless that medium does a better job of explaining and facilitating the decision of legal problems than our current vocabulary. Judges should constantly ask how much is gained in precision and enlightenment before going to the trouble of restating any legal question in economic terms.

56. Bork, supra note 7 , at 22.

57. Samuels \& Mercuro, supra note 27, at 110-14; Comment, supra note 27, at 1158.

58. Tribe, supra note 39 , at 596 .

59. Spaeth, supra note 40 , at 13 .

60. Bork, supra note 7 , at 23. 


\section{How (Not) to Use Economic Analysis}

An additional set of limits also requires discussion: those which arise in deciding how to use economic analysis when it is warranted. Judicial use of economic predictive techniques, like ex ante analysis, and the area of statutory interpretation merit special attention.

\section{A. Use of Economic Forecasting Techniques}

Judge Eastberbrook has admonished judges to view cases from an ex ante perspective and to analyze how their decisions will affect the behavior of individuals or firms at the margin. Ex ante analysis involves looking beyond the instant controversy to situations involving other persons who have not yet acted, and attempting to predict their behavior in response to one or another incentive or disincentive. Marginal analysis complements ex ante analysis by directing the focus of judges "on the margin" where people can substitute one product or kind of behavior for another. ${ }^{61}$

One example Judge Eastberbrook employs to illustrate both ex ante and marginal analysis is Blum v. Stenson. ${ }^{62}$ In this case the Supreme Court held that public interest lawyers should be reimbursed under statutes providing for attorneys' fees at the same rate as private counsel with equivalent experience. The Court rejected the defendants' ex post argument that, since the case had already been brought and paid for, all the public interest lawyers needed were their actual costs plus a fair profit. ${ }^{63}$ Instead, the Court adopted the ex ante perspective that other worthy cases might never be brought unless lawyers are attracted to public interest practice by comparable pay. ${ }^{64}$ Similarly, the defendants' argument focused on average costs, that is whether the fees awarded would be high enough to keep the public interest group in business given the sum total of its resources. The Court, however, assumed that the public interest group's decisionmaking would take place at the margin; it would bring the next case only if the anticipated marginal benefits, which are a function of the size of the fee award discounted by the probability of winning, would exceed its marginal costs. ${ }^{65}$

That example sounds eminently reasonable, and surely there are many other cases in which the ex ante and marginal approaches make sense. But inevitably there are more difficult cases where just telling judges to view problems from an ex ante perspective will not help them to identify the myriad of possible situations that one decision or another might affect, or even which situations are more important than the rest. The outcome of ex

61. See also Easterbrook, supra note 19, at 10-14.

62. 465 U.S. 886 (1984).

63. Id. at 894-895.

64. Id. at 894 .

65. Easterbrook, supra note 19 , at $31,33-34$. 
ante analysis-and of forecasting on the margin-depends on one's perspective, the questions one asks, and the breadth of one's imagination.

In his analysis of the opinion in Allen $v$. Wright, ${ }^{66}$ for instance, Judge Easterbrook assumes that the IRS makes enforcement decisions at the margin by comparing one case to another, rather than by evaluating cases against an abstract standard of performance. ${ }^{67}$ While that may sometimes be true, at other times agencies must allocate enforcement resources in conformity with explicit statutory commands, and in those cases courts may hold the agency to a fixed standard of performance. ${ }^{68}$ In still other cases, the court must supplement marginal analysis with an assessment of how its proposed ruling will affect average or overall activity levels. Professor Mark Kelman uses the example of a polluter who might be permitted to continue operation under a marginal analysis even though the most efficient outcome, when overall activity levels are considered, is to close the plant. ${ }^{69}$ In short, a call for marginal analysis offers judges only a directional signal, not a fixed course.

Currently, most judges confine the scope of their forecasting to future situations which have been raised by the parties before them, or which their common sense tells them might occur. It is not at all clear how a purposeful ex ante marginal viewpoint would change the boundaries of the predictive exercise. If indeed the discipline of economics can really help us in defining how far to widen our lens and how to locate the margins, perhaps a critical task-not yet undertaken-is to explain the process and mechanics to economically unsophisticated judges.

Another fundamental problem with marginal analysis is deciding whether to accept the economists' vision of how people will respond to economic incentives. Professor Lewis Kornhauser believes that economic theory is likely to be a plausible predictor of corporate behavior because corporations make decisions as rational, economic agents. However, he also thinks economics is much less of an accurate predictor of the behavior of individuals who often "act on grounds that economists would not consider 'rational.' "7o Real people-with all their intellectual, emotional, and physical idiosyncrasies-are not as bound to marginal costs and benefits as are the economists' rational maximizers. "Just as traditional French cooking does not use seaweed or raw fish," one authority has noted, "so neoclassical models do not make assumptions derived from psychology, anthropology, or sociology."71 Although a few second wave law and economics people do acknowledge that primal emotions-such as love, rage, jealousy, and

66. 468 U.S. 737 (1984).

67. Easterbrook, supra note 19 , at 41-42.

68. See Heckler v. Chaney, 470 U.S. 821, 833 (1985) (Decisions not to take enforcement action are presumptively unreviewable but the presumption is rebuttable by statutory language which supplies specific standards to which agency can be held.).

69. Kelman, Misunderstanding Social Life: A Critique of the Core Premises of "Law and Economics, " $33 \mathrm{~J}$. Legal Educ. 274, 279 \& n.18 (1983).

70. Kornhauser, supra note 50, at 636-37.

71. G. AKerlof, supra note 9, at 2. 
altruism-and alliances among families, tribes, and groups are important anthropological restraints on self-interested behavior, too many economists ignore them. ${ }^{72}$ While irrational or even altruistic behavior may have no place in the world of neoclassical economics, it is pervasive in the world of law. Much litigation, in fact, arises out of irrational behavior. The ex ante perspective instructs the judge to look beyond the parties' prior irrational or altruistic behavior. But in doing so, it seems reasonable for the judge to assume that, having happened once, irrational and altruistic behavior will occur again in the future.

In short, economic forecasting techniques help to frame the type of inquiry that a judge should conduct in order to assess the consequences of her decision in advance. Unfortunately, the techniques of ex ante and marginal analysis offer only the broadest of guidance as to what judges should look at or for in any particular case. In addition, they implicitly require the judge to accept and indeed encourage a sometimes counterintuitive notion that people's behavior will generally be based on maximizing their self-interest. For many of us, they suggest one but not the only base to touch in judicial decisionmaking.

\section{B. Statutory Construction}

Judges on our court spend the greatest part of their time construing statutes. Here, too, ardent legal economists, chiefly Judges Posner and Easterbrook, have formulated a concept of statutory construction based on the economists' theory of how the legislative process operates. Their approach, however, is by no means universally accepted by all the law and economics commentators. ${ }^{73}$ Under this standard, laws are bought and sold just like other commodities; because some special interest groups can make their demands more effectively than others in the legislative forum, many, if not most, laws further private, rather than public, interests. Such private interest laws are, in effect, "deals" between legislators and special interest groups and courts should construe them narrowly in order to enforce the deals according to their terms. On the other hand, those few laws which are truly enacted to serve the public interest should be construed broadly to effectuate their public purpose. ${ }^{74}$

This approach to statutory construction spawns problems at two different levels. First, the validity of its theory is dubious and an inconsistency exists between this theory and other parts of law and economics ideology. Second, in light of current Supreme Court precedent about the role of agencies in statutory construction, difficulty arises for judges in incorporating the theory into federal jurisprudence.

All of us who have worked on legislation know the old saying about laws and sausage: No one should look into how either is made. We are also aware

72. Hirschleifer, supra note 5 , at $26,30,36-37$.

73. Note, supra note 10 , at $885-87$.

74. R. POSNER, supra note 8, at 261-72; Easterbrook, supra note 19, at 14-18. 
of Mark Twain's caution that "no man is safe while Congress is in session." There is a difference, however, between acknowledging the reality of lobbyists, PACs, and dealmaking, and building a theory of statutory construction that allows judges to demote the importance of the end product because of flaws in that process.

If legislators and special interest groups bargain about laws in a political marketplace, and if the marketplace is such an efficient allocator of resources for all other purposes, why is legislation the only market transaction consistently presumed to come out "wrong" in terms of efficiency? Professor Hovencamp, among others, has argued that the political marketplace is as likely to be as efficient as any other, and criticized the trade-off method of statutory construction as "manifestly inconsistent with the general Chicago theory that when a market speaks-even a political market-the presumption is very strong that it should be listened to."75 Other commentators similarly challenge the Chicago School's view of the comparative efficiency quotient of courts and legislatures. They suggest that statutory solutions are generally efficient and should be accorded preference over the common law whose inefficiencies, they claim, spurred the codification movement. ${ }^{76}$

The position that courts tend to make wealth maximizing decisions but legislatures do not has some troublesome political and jurisprudential implications, for it elevates the judiciary as societal decisionmakers at the expense of the legislature. Because economists' "interest group theory [of legislation leads] to suspicion about much of what Congress does, [it creates] a climate hospitable to judicial interference with legislative outcomes." 77 The economists' move to equate public interest statutes with efficiency and special interest statutes with inefficiency "is little more than an attempt to force a particular concept of efficiency into the democratic marketplace."78 The result of the economists' "insight" is thus to reduce judges' incentives to exercise self-restraint in encroaching on the prerogatives of the legislaturesomething that the economists who are proponents of structural, separationof-powers judicial restraint should abhor.

A related problem grows out of Professor Tribe's observation that treating "statutes as commodities, and lawmaking as little more than logrolling, . . . tends to demean the law and drain politics of its moral and intellectual content."79 Many judges would probably be nervous about a method of statutory construction which unquestionably accepts and even advances this slightly seamy view of our coordinate branch. However, even if judges believe that Congress is prone to passing harmful legislation because of flaws in the political marketplace, they may just as likely react not by enforcing the antipublic-interest deal as made, but rather by resorting to more traditional

75. Hovencamp, supra note 48 , at 255 \& n. 198 .

76. Note, supra note 10 , at $885-87$.

77. Macey, Promoting Public-Regarding Legislation Through Statutory Interpretation: An Interest Group Model, 86 Colum. L. Rev. 223, 224 (1986).

78. Hovencamp, supra note 48 , at 253

79. Tribe, supra note 39 , at 616 \& n. 146 . 
modes of statutory construction which can "transform statutes designed to benefit narrow interest groups into statutes that in fact further the public interest." 80 Professor Jonathan Macey has explained that judges who stick with traditional methods of construction, focusing on the words of a statute rather than its origins, may well interpret the broad public interest language in which legislative deals are often disguised to "reach a result that serves the public interest, but fails to honor the terms of the original deal between the legislature and the interest group." 81 Thus, it does not follow from the economists' cynical vision of the legislative process that judges will follow their narrow approach to judicial review.

The economists' general theory of statutes is supplemented by Judge Easterbrook's meta-rule of construction: A statute should not be applied to any but those situations expressly mentioned by the drafters, unless the legislature explicitly delegated to the courts the power to create or revise a form of common law in a certain area. ${ }^{82}$ Because Congress rarely does the latter, this rule means that most law is left up to the private parties and most disputes between private parties are left to be decided by judge-made law. In Judge Easterbrook's' words, “[a]ll things are permitted unless there is some contrary rule."'83 This approach to statutory construction increases the costs of public interest legislation by forcing a legislature to be very explicit whenever it wants to act in the public interest. Thus, this seemingly "neutral" theory of statutory construction leads inexorably to more narrow consruction of more statutes and to more private governance. This translates roughly into more power for, and less regulation of, those who do not need laws to protect them.

Another problem is how judges can distinguish between private interest and public interest laws. In the absence of fraud or bribery, judges traditionally do not probe into the motives of legislators, but restrict themselves to determining the express intent or purpose of legislative action. ${ }^{84}$ Not only is legislative motive difficult to ascertain, but in many cases legislators' motives-like the legislation they spawn-are mixed: A hand to a friendly group here, a bone to the public interest there. Errors in ascertaining legislative intent will be costly; whenever judges "mistakenly interpret public interest statutes as special interest statutes . . some interest group receives a windfall at the expense of the public." 85

As an alternative to investigating motive, Judge Easterbrook suggests looking at whether the statutory language is general or specific, whether there are any "indicia of rent-seeking legislation" (such self-serving provisions for a particular group as limits on entry or subsidies), and what went on during the

80. Macey, supra note 77 , at 227.

81. Id. at 252.

82. Easterbrook, supra note 32 , at $539,544$.

83. Id. at 549-50.

84. 2A J.G. Sutherland, Statutory Construction $\$ 48.17$, at 340 (4th ed. 1984 ).

85. Macey, supra note 77 , at 239. 
process of passing the bill. ${ }^{86}$ It is difficult to envision judges redirecting a major part of their efforts to exploring what "deal" was actually cut in the corridors and backrooms of Congress, or even taking "judicial notice" of the horsetrading we all know goes on. As one critic has written, "[j]udges interpret statutes; they are not investigative reporters." 87 Furthermore, that which may be an indicium of rent-seeking legislation for one judge could be a sign of public interest for another. Professor Tribe's example of a rent control ordinance may look like a private interest bill to an economist while striking many people as a public interest initiative designed for the betterment of the whole community. ${ }^{88}$

Finally, as a sitting judge I must note that even if economically-devout judges could somehow overcome all of these hurdles and decide whether the statutory provision was a public interest enactment to be construed broadly or a private interest law to be construed narrowly, their exercise would be largely useless under the Chevron Supreme Court precedent. Since the Court's Chevron decision, ${ }^{89}$ a court must defer to an agency's interpretation of a statute unless Congress has spoken clearly on the specific interpretation or the agency's interpretation is so out of sync with the statute that it would accomplish an absurd result. Absent these two situations, if there is ambiguity in the statute-and who would doubt that a determined judge can always find an ambiguity ${ }^{90}$ - the court must seriously consider deferring to the agency's interpretation.

The law and economics proponents' views of administrative agencies run 180 degrees counter to the deference required by the Chevron approach: They see administrative agencies as interlopers in the process of statutory construction. Unlike the courts, agencies never will be content to enforce the basic deal cut in Congress. In the economists' view, private interests press for the creation of agencies in order to circumvent the courts and create " $a$ form of 'dependent' judiciary designed to promote the operation of interest group politics rather than allocative efficiency."'91 The Supreme Court precedent thus poses a serious impediment to implementing the economists' theory of statutory construction, at least where an agency has first crack at interpretation. Legal economists may have to aim their fire more directly at either the administrative agencies or the Supreme Court itself.

86. Easterbrook, supra note 19, at 16-17.

87. Macey, supra note 77 , at 239.

88. Tribe, supra note 39 , at 615 .

89. Chevron, U.S.A., Inc. v. NRDC, 467 U.S. 837 (1984). But of. INS v. Cardozo-Fonseca, 55 U.S.L.W. 4313 (U.S. Mar. 9, 1987); Breyer, Judicial Review of Questions of Law and Policy, 38 ADMIN. L. REv. 363 (1986).

90. See Easterbrook, Legal Interpretation and the Power of the Judiciary, 7 Harv. J. L. \& Pub. PoL'y 87, 91 (1984).

91. R. Posner, supra note 2 , at 480. 


\section{CONCLUSION}

There are distinct limits to the methodology of law and economics at both the macro level of theory and the micro level of application. Because economic theory is constantly being debated among legal academics, judges may draw on many sources to form their own views on this level of the debate. There is no similar body of literature, however, which addresses questions about the application of these theories. Case studies are needed on how to conduct economic analyses in our present resource-poor, adversarial system and on how the results might differ from our usual judicial fumblings.

It is unlikely that anyone will convince most sitting judges to adopt one decisionmaking technique or framework of analysis for every case, especially if that framework incorporates powerful and controversial assumptions. On the other hand, judges are always looking for new tools to add to their existing array of analytic techniques, hoping to make their opinions tighter and righter. Before using such tools, however, other judges will ask many of the same questions posed here. Can these techniques be used in some cases without accepting and advancing critical premises of the whole law and economics school? In which cases should these techniques be used? What happens when the parties have not framed their dispute in economic terms? How can the language be adapted to make it comprehensible to fellow judges, to the parties, and to the decisionmakers themselves? Is it necessary to predict people's behavior on the assumption that they always maximize wealth for themselves? How do these techniques fit into rules of statutory construction laid down by the Supreme Court?

My own conclusion is that economic analysis has growing importance in judicial decisionmaking and may often be more useful than the rudimentary analytic techniques to which courts have traditionally adhered. Judges are eager for more enlightenment on when and how to use this analysis. There are, however, some core beliefs that many judges share about the function of law and courts in our society that will always rise above the rules of the economists' marketplace. Because some of the economists' assumptions and theories are neither intuitively persuasive, nor documented to any degree, I would find it premature to adopt them as tenets for a comprehensive jurisprudential philosophy. I am particularly troubled by the major shifts in the roles and balance of power among the executive, legislative, and judicial branches which legal economists seem to advocate. At this point, I am (and I would guess many other judges are) content to be labelled an economically aware, but not an economically sophisticated, judge. 